NASA/TM-2002-211797

AIAA-2002-3919

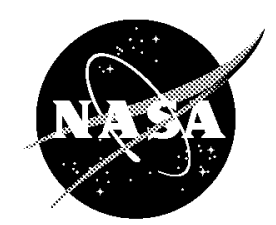

\title{
Conceptual Design of a Supersonic Business Jet Propulsion System
}

Robert J. Bruckner

Glenn Research Center, Cleveland, Ohio 
The NASA STI Program Office ... in Profile

Since its founding, NASA has been dedicated to the advancement of aeronautics and space science. The NASA Scientific and Technical Information (STI) Program Office plays a key part in helping NASA maintain this important role.

The NASA STI Program Office is operated by Langley Research Center, the Lead Center for NASA's scientific and technical information. The NASA STI Program Office provides access to the NASA STI Database, the largest collection of aeronautical and space science STI in the world. The Program Office is also NASA's institutional mechanism for disseminating the results of its research and development activities. These results are published by NASA in the NASA STI Report Series, which includes the following report types:

- TECHNICAL PUBLICATION. Reports of completed research or a major significant phase of research that present the results of NASA programs and include extensive data or theoretical analysis. Includes compilations of significant scientific and technical data and information deemed to be of continuing reference value. NASA's counterpart of peerreviewed formal professional papers but has less stringent limitations on manuscript length and extent of graphic presentations.

- TECHNICAL MEMORANDUM. Scientific and technical findings that are preliminary or of specialized interest, e.g., quick release reports, working papers, and bibliographies that contain minimal annotation. Does not contain extensive analysis.

- CONTRACTOR REPORT. Scientific and technical findings by NASA-sponsored contractors and grantees.
- CONFERENCE PUBLICATION. Collected papers from scientific and technical conferences, symposia, seminars, or other meetings sponsored or cosponsored by NASA.

- SPECIAL PUBLICATION. Scientific, technical, or historical information from NASA programs, projects, and missions, often concerned with subjects having substantial public interest.

- TECHNICAL TRANSLATION. Englishlanguage translations of foreign scientific and technical material pertinent to NASA's mission.

Specialized services that complement the STI Program Office's diverse offerings include creating custom thesauri, building customized data bases, organizing and publishing research results... even providing videos.

For more information about the NASA STI Program Office, see the following:

- Access the NASA STI Program Home Page at http://wwo.sti.nasa.gov

- E-mail your question via the Internet to help@stinasa.gov

- Fax your question to the NASA Access Help Desk at 301-621-0134

- Telephone the NASA Access Help Desk at 301-621-0390

- Write to: NASA Access Help Desk NASA Center for AeroSpace Information 7121 Standard Drive Hanover, MD 21076 
NASA/TM-2002-211797

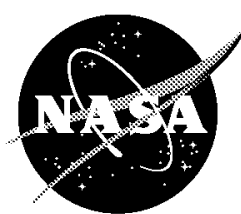

\section{Conceptual Design of a Supersonic Business Jet Propulsion System}

Robert J. Bruckner

Glenn Research Center, Cleveland, Ohio

Prepared for the

38 th Joint Propulsion Conference and Exhibit

cosponsored by the AIAA, ASME, SAE, and ASEE

Indianapolis, Indiana, July 7-10, 2002

National Aeronautics and

Space Administration

Glenn Research Center 
Available from

NASA Center for Aerospace Information 7121 Standard Drive

Hanover, MD 21076
National Technical Information Service 5285 Port Royal Road Springfield, VA 22100

Available electronically at http://glrs.grcnasa.gov 


\title{
Conceptual Design of a Supersonic Business Jet Propulsion System
}

\author{
Robert J. Bruckner \\ National Aeronautics and Space Administration \\ Glenn Research Center \\ Cleveland, Ohio 44135
}

\begin{abstract}
NASA's Ultra-Efficient Engine Technology Program (UEETP) is developing a suite of technology to enhance the performance of future aircraft propulsion systems. Areas of focus for this suite of technology include: Highly Loaded Turbomachinery, Emissions Reduction, Materials and Structures, Controls, and Propulsion-Airframe Integration. The two major goals of the UEETP are emissions reduction of both landing and take-off nitrogen oxides (LTO-NO $\left.{ }_{\mathrm{X}}\right)$ and mission carbon dioxide $\left(\mathrm{CO}_{2}\right)$ through fuel burn reductions. The specific goals include a $70 \%$ reduction in the current $\mathrm{LTO}-\mathrm{NO}_{\mathrm{X}}$ rule and an $8 \%$ reduction in mission $\mathrm{CO}_{2}$ emissions. In order to gain insight into the potential applications and benefits of these technologies on future aircraft, a set of representative flight vehicles was selected for systems level conceptual studies. The Supersonic Business Jet (SBJ) is one of these vehicles. The particular SBJ considered in this study has a capacity of 6 passengers, cruise Mach Number of 2.0, and a range of 4,000 nautical miles. Without the current existence of an SBJ the study of this vehicle requires a two-phased approach. Initially, a hypothetical baseline SBJ is designed which utilizes only current state of the art technology. Finally, an advanced SBJ propulsion system is designed and optimized which incorporates the advanced technologies under development within the UEETP. System benefits are then evaluated and compared to the program and design requirements. Although the program goals are only concerned with LTO-NO $\mathrm{X}_{\mathrm{X}}$ and $\mathrm{CO}_{2}$ emissions it is acknowledged that additional concerns for an SBJ include take-off noise, overland supersonic flight, and cruise $\mathrm{NO}_{\mathrm{x}}$ emissions at high altitudes. Propulsion system trade-offs in the conceptual design phase acknowledge these issues as well as the program goals. With the inclusion of UEETP technologies a propulsion system is designed which performs at $81 \%$ below the $\mathrm{LTO}-\mathrm{NO}_{\mathrm{X}}$ rule, and reduces fuel burn by $23 \%$ compared to the current technology.
\end{abstract}

Nomenclature

$\begin{array}{ll}\text { BPR } & \text { Bypass Ratio } \\ F & \text { figure of merit } \\ \text { Fn } & \text { Engine thrust } \\ \text { Fn lapse } & \text { Engine thrust at TOC/Engine thrust at SLS } \\ \text { FPR } & \text { Fan Pressure Ratio } \\ \text { HPC } & \text { High Pressure Compressor } \\ \text { LTO } & \text { Landing and Take-Off } \\ \text { NO }_{x} & \text { Nitrogen oxides } \\ \mathrm{P}_{3} & \text { compressor discharge pressure } \\ \text { SBJ } & \text { Supersonic Business Jet } \\ \text { SLS } & \text { Sea Level Static } \\ \mathrm{T}_{3} & \text { compressor discharge temperature } \\ \mathrm{T}_{4} & \text { combustor discharge temperature } \\ \text { TOC } & \text { Top Of Climb } \\ \text { TTR } & \text { Throttle Ratio } \\ \text { UEETP } & \text { Ultra-Efficient Engine Technology Program } \\ \text { Wc } & \text { Corrected weight flow } \\ \text { Wc lapse Wc at TOC/Wc at SLS } \\ \alpha_{1-5} \quad \text { coefficients of the figure of merit surfaces } \\ \Phi & \text { independent variable fan pressure ratio } \\ \tau & \text { independent variable throttle ratio }\end{array}$

\section{Introduction}

NASA's Ultra Efficient Engine Technology Program (UEETP) is developing a suite of technology to enhance the performance of future aircraft propulsion systems. Areas of focus for this suite of technology include: Highly Loaded Turbomachinery, Emissions Reduction, Materials and Structures, Controls, and Propulsion-Airframe Integration. The two major goals of the UEETP is emissions reduction of both landing and take-off nitrogen oxides (LTO-NO ${ }_{\mathrm{X}}$ ) and mission carbon dioxide $\left(\mathrm{CO}_{2}\right)$ through fuel burn reductions. The specific goals include a $70 \%$ reduction in the current $\mathrm{LTO}-\mathrm{NO}_{\mathrm{X}}$ rule and an $8 \%$ reduction in mission $\mathrm{CO}_{2}$ emissions.

The commercial jet aircraft fleet is quite uniform in its appearance and function and has been this way for 
several decades. The common features include a cylindrical fuselage mounted on top of a slender, swept wing with under-hung engines at the leading edge flying at high subsonic speeds. However, the SBJ vehicle chosen for this study follows the more current trend of smaller jet aircraft. In addition to its smaller size, the SBJ also incorporates the desire for speed beyond the high subsonic Mach Numbers of the modern commercial fleet.

The high end of commercial travel is eroding from the large commercial carriers [1] and being deposited into the business jet market, which has seen dramatic growth in recent years. As such, the acquisition cost of today's high-end business jets is no longer that much different from the projected cost of a SBJ. This commercial argument for the analysis of the SBJ seems powerful enough to include this aircraft in the program. However, this does not consider other potential applications of a small supersonic aircraft such as military use and the delivery of time-critical payloads. The selection of a small yet fast aircraft to represent the supersonic technologies of UEETP is based upon the historical success of first developing aircraft speed followed by the ensuing growth in size.

Without the existence of a current SBJ in today's aircraft market, this study required a two-phased approach. The initial phase required the design of a current technology SBJ engine and vehicle that is representative of what might be possible given the current state-of-the-art. The second phase of the study included the addition of the UEETP technologies to the baseline mixed-flow turbofan engine and a parametric study that examined the effects of throttle ratio and fan pressure ratio on the final vehicle design. A final engine design was then selected from this parametric study. Preliminary component designs were carried out on the final engine to add confidence to the conceptual design philosophy and weight estimates. An economic analysis was also conducted on the final engine.

\section{SBJ Design Requirements}

The mission requirements of the SBJ are rather standard for a civilian aircraft with the exception of the supersonic cruise Mach number. The SBJ, which is considered in this study, has a capacity for 6 passengers, range of 4,000 nautical miles, and cruise Mach number of 2.0. A complete listing of the mission requirements is presented in Table 1 . The SBJ conceptual design is also constrained emissions, noise and affordability. The first of these, emissions, include the LTO-NO $\mathrm{X}_{\mathrm{X}}$ and mission $\mathrm{CO}_{2}$ goals of the
UEETP as well as the mission $\mathrm{NO}_{\mathrm{X}}$ due to the higher cruising altitude of the SBJ. The noise constraint is primarily a take-off issue and is evaluated by using exhaust jet velocity as a surrogate for jet noise and applying appropriate acoustic attenuation methods. This constraint also manifests itself in the overland supercruise scenario. In order to make the SBJ more economically viable, overland supersonic flight is desirable. Although the UEETP does not address sonic boom issues, the assumption for this study is that in the timeframe required to bring the UEETP engine technologies to maturity, complementary airframe programs will develop technologies, which will make overland supersonic flight possible. The constraint of affordability in the conceptual design phase is only evaluated on the final, selected engine.

\section{Current Technology Engine Design}

The only propulsion system type, which is considered in both the baseline design as well as the advanced technology design, is the low bypass ratio mixedflow turbofan engine.

A summary of the main engine cycle parameters that were used in the current technology design is contained in Table 2. Figure 1 shows a cross section of the baseline engine. This engine is not meant to represent any particular engine available today. Rather, it is representative of the type of engine that could be built for the SBJ with the current state of the art.

\section{UEETP Technology Suite}

The technology developed by the UEETP falls into the following categories: Highly Loaded Turbomachinery, Emissions Reduction, Materials and Structures, Controls, and Propulsion-Airframe Integration. The specific technologies, which are applied to the SBJ, are detailed in Table 3. Some of the key engine cycle parameters were chosen as follows. The overall pressure ratio was selected such that the maximum compressor discharge pressure, $\mathrm{P}_{3}$, was achieved at the top of climb point, Mach Number 2.0 and 50,000 feet altitude. The bypass ratio was selected to yield an extraction ratio, the ratio of bypass to core stagnation pressure, of 1.05 at the cycle design point. Fan pressure ratio and throttle ratio, the ratio of maximum temperature at top of climb to the maximum temperature at sea level static, were varied in the parametric study of the design space. All of the engine cycles in the parametric study used a velocity coefficient of 0.975 , a 
mixer-ejector nozzle to suppress take-off noise, 75 horsepower take-off from the high pressure spool, 0.5 pounds per second of customer bleed at the compressor discharge, $4.65 \%$ non-chargeable cooling flow for the high pressure turbine, $0.96 \%$ chargeable cooling flow to the high pressure turbine, and no cooling to the low pressure turbine.

\section{Advanced Technology Design Space Study}

A preliminary design space was investigated which ranged from 2.4 to 3.6 in fan pressure ratio and from 1.104 to 1.149 in throttle ratio. Five engines, designated e1 through e5, were included in the cycle, aeromechanical, mission, and aircraft sizing analysis. Mission block fuel, aircraft take-off gross weight, LTO- $\mathrm{NO}_{\mathrm{X}}$, mission $\mathrm{NO}_{\mathrm{X}}$, and ideal mixed jet velocity were used as figures of merit to evaluate the design space of this parametric study. Contour surfaces were modeled which examined the first order effects of both fan pressure ratio and throttle ratio, second order effects of fan pressure ratio, and the interaction of both parameters. As such the mathematical form of the figure of merit surfaces is detailed below.

$$
\mathrm{F}(\tau, \phi)=\alpha_{1}+\alpha_{2} \tau+\alpha_{3} \phi+\alpha_{4} \phi^{2}+\alpha_{5} \tau \phi
$$

Here $\mathrm{F}(\tau, \phi)$ represents one of the figures of merit, mission block fuel, take-off gross weight, LTO-NO mission $\mathrm{NO}_{\mathrm{X}}$, or unsuppressed sea level static, SLS, jet velocity. The coefficients, $\alpha_{1-5}$, are calculated deterministically from the results of the five e-series engines.

The initial design space contours indicated that the optimum engine selection would lie near the point of 3.0 fan pressure ratio and maximum achievable throttle ratio. However this point is difficult to determine precisely since at high throttle ratio the maximum $\mathrm{T}_{4}$ may not be achieved in the engine cycle. In order to design the most compact and efficient engine possible given the UEET suite of technologies it is desirable to reach the maximum $\mathbf{T}_{4}$. Therefore, the strategy used to determine the optimum engine design included designing a new series of 12 engines in the range of 2.8 to 3.2 fan pressure ratio and 1.108 to maximum achievable throttle ratio. These engines were designated $\mathrm{f} 1$ through f12. Contour plots of the five figures of merit are shown in figures 2-6. The contours in these figures are calculated based on the initial set of five engines, e1 through e5. The second series of engines, $\mathrm{f} 1$ through $\mathrm{f12}$, are shown on the figures to illustrate the region of focus.
Figures 2 and 3 contain the contours of mission fuel weight and take-off gross weight. The trends in both figures indicate that for the minimum fuel burn and system weight it is desired to move the design toward higher throttle ratio and medium fan pressure ratio. This trend provides for the minimum fuel burn that in turn maximizes the $\mathrm{CO}_{2}$ reduction. It also minimizes the overall weight, which has historically been a very accurate predictor of cost.

Figure 4 contains the contour of mission $\mathrm{NO}_{\mathrm{X}}$ emissions. Here the trend for minimizing mission $\mathrm{NO}_{\mathrm{X}}$ is to move toward higher fan pressure ratios at low throttle ratios, but is somewhat independent of fan pressure ratio at higher throttle ratio. Therefore, this figure of merit also indicates a desire to move toward both higher throttle ratio and fan pressure ratio.

Figure 5 contains the LTO-NO $\mathrm{X}_{\mathrm{X}}$ trends. Here the desire to minimize LTO-NO $\mathrm{N}_{\mathrm{X}}$ emissions would indicate a trend toward higher throttle ratios and lower fan pressure ratios. However, not highlighted on this figure is the fact that the entire design space investigated by this parametric study satisfies the UEETP goal of a $70 \%$ LTO-NOX $_{X}$ reduction from the current rule. Similar to the mission $\mathrm{NO}_{\mathrm{X}}$ figure of merit, the trend for minimizing LTO-NO $\mathrm{X}_{\mathrm{X}}$ is to move toward as high of a throttle ratio as is possible while still achieving the maximum $\mathrm{T}_{4}$ allowed under the UEETP technologies.

Finally, in figure 6 the ideal, unsuppressed jet velocity is shown as a surrogate for take-off noise. The trend that lower jet velocities yield quieter aircraft indicates that the SBJ engine should be designed at lower fan pressure ratios. However, all the engines shown in the design space would require some means of noise suppression based on the projected noise rule for this type of aircraft. The jet velocity also appears to be rather insensitive to the throttle ratio.

The selection of engine $\mathrm{f} 6$ was made as the best choice in balancing all of the desired figures of merit for this conceptual design. All of the figures of merit showed a trend toward higher throttle ratio with the exception of SLS jet velocity. The jet velocity trend showed very little sensitivity to throttle ratio and was primarily driven by fan pressure ratio. Engines f1, $\mathrm{f} 5$, and $\mathrm{f} 12$ were not selected because these engines did not reach the maximum allowable temperatures at top of climb, TOC, which is an indication that they were throttled back too much at the design point. The block fuel, take-off gross weight, and the jet velocity determined the fan pressure ratio selection of 
3.0. While the $\mathrm{f} 6$ and $\mathrm{f} 10$ engines showed comparable fuel and gross weight, the decision for the selection of the lower fan pressure ratio was driven by the reduced SLS jet velocity. A summary of the $\mathrm{f} 6$ engine characteristic as well as a conceptual flowpath design is contained in Table 4 and Figure 7 respectively.

Upon selection of the optimum SBJ engine from the design space of the f series engines a preliminary component design exercise was perform which substantiated many of the assumptions of the flowpath design and weight estimations of the conceptual phase. An economic analysis was performed which indicated that the Supersonic Business Jet, which incorporates the UEETP technologies, would reduce the cost of the aircraft by nearly $14 \%$.

\section{Summary}

A propulsion system has been designed for a supersonic business jet, which incorporates the advanced technologies of NASA's Ultra Efficient Engine Technology Program. A parametric study was performed over a range of fan pressure ratio and throttle ratio to determine the optimum engine configuration for these conditions. Based on the UEETP goals of reduced $\mathrm{CO}_{2}$ and LTO-NO emissions as well as ancillary considerations of minimum take-off gross weight, mission $\mathrm{NO}_{\mathrm{x}}$ emissions, and projected take-off noise, the final engine was designed to have a fan pressure ratio of 3.0 and throttle ratio of 1.143 . The resultant system satisfied all program goals by reducing fuel burn by over $23 \%$ compared to the current technology system and produced LTO-NO $\mathrm{NO}_{\mathrm{x}}$ at $81 \%$ below the current rule.

\section{References}

${ }^{1}$ Aboulafia, Richard, "The Business Case for Higher Speed," Aerospace America, AIAA, July, 2001. 


\begin{tabular}{|c|c|}
\hline $\begin{array}{l}\text { SBJ design } \\
\text { constraints }\end{array}$ & requirements and \\
\hline Mission & \\
\hline Payload & 6 passengers \\
\hline Range & 4000 nautical miles \\
\hline Cruise Speed & 2.0 Mach Number \\
\hline Cruise Altitude & $(50,000-60,000)$ feet \\
\hline Emissions & \\
\hline LTO-NO & $-70 \%$ compared to current rule \\
\hline Mission $\mathrm{CO}_{2}$ & $\begin{array}{l}-8 \% \text { compared to current } \\
\text { technology }\end{array}$ \\
\hline Cruise $\mathrm{NO}_{\mathrm{x}}$ & minimize high altitude impact \\
\hline Noise & \\
\hline Takeoff & Suppressed to current rules \\
\hline Cruise & Overland supersonic flight \\
\hline Economics & \\
\hline Affordability & $\begin{array}{l}\text { Evaluated for baseline and } \\
\text { final design }\end{array}$ \\
\hline
\end{tabular}

Table 1. SBJ design requirements and constraints

\begin{tabular}{|l|c|}
\hline \multicolumn{2}{|c|}{ SBJ Baseline Propulsion System } \\
\hline FPR, $\Phi$ & 2.80 \\
\hline HPC PR & 9.60 \\
\hline BPR Des & 1.21 \\
\hline$T_{4}$ Max (deg. R) & 3385 \\
\hline$T_{4}$ Des (deg. R) & 3160 \\
\hline SLS Jet Velocity (fps) & 1808 \\
\hline & 1.071 \\
\hline TTR, $\tau$ & 0.825 \\
\hline Wc lapse & 0.30 \\
\hline Fn lapse & 22112 \\
\hline & 0.594 \\
\hline Fn SLS $(\mathrm{lbf})$ & 6385 \\
\hline SFC SLS $[(\mathrm{lbm} / \mathrm{hr}) / \mathrm{lbf}]$ & 1.170 \\
\hline Fn TOC $(\mathrm{lbf})$ &. \\
\hline SFC TOC $[(\mathrm{lbm} / \mathrm{hr}) / \mathrm{lbf}]$ & 119294 \\
\hline & 52488 \\
\hline TOGW $(\mathrm{lbm})$ & 60.96 \\
\hline Block Fuel $(\mathrm{lbm})$ & 1427 \\
\hline LTO NO $(\mathrm{g} \mathrm{NOx} / \mathrm{kN})$ & \\
\hline Mission NO$(\mathrm{lbm})$ &
\end{tabular}

Table 2. Current Technology Engine Design Cycle Parameters

\section{SBJ-Baseline Propulsion System Thrust SLS (LBF) = 22,112 Engine Pod Weight $($ LBF $)=11,599$}

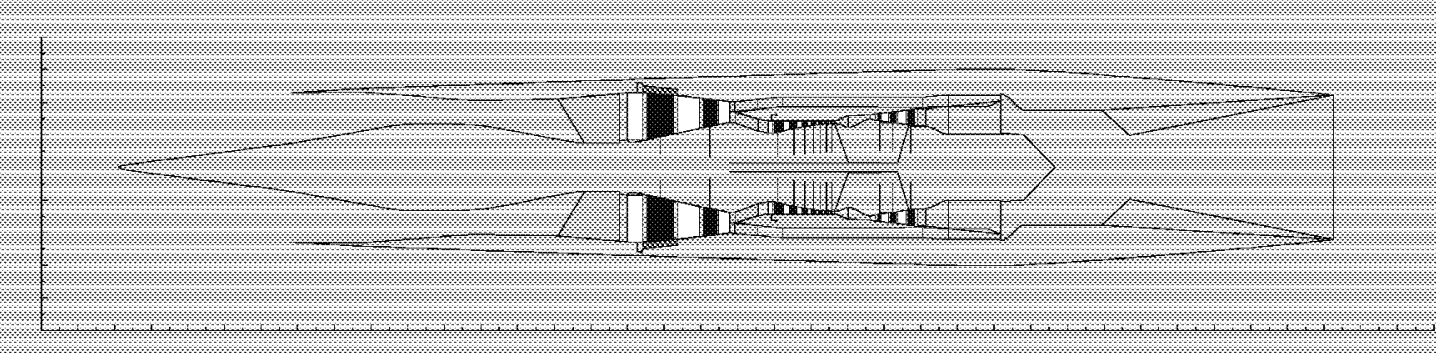

Figure 1. SBJ Baseline Propulsion System 


\begin{tabular}{|c|c|}
\hline Technology Name & Maximum Technology Impact \\
\hline $\begin{array}{l}\text { Emission Reduction for Regional } \\
\text { Engines }\end{array}$ & $\begin{array}{l}-70 \% \text { Emission Index; Reduce combustor liner } \\
\text { cooling to } 10 \%\end{array}$ \\
\hline High-Loaded Multistage Compressor & $\begin{array}{l}\text { Increase fan/HPC loading by } 50 \% ; \text { Increase } \\
\text { fan/HPC polytropic efficiency by } 1 \%\end{array}$ \\
\hline High-Loaded HP/LP Turbine Systems & $\begin{array}{l}\text { Increase HPT/LPT loading by } 25 \% \text {; increase } \\
\text { LPT adiabatic efficiency by } 1 \%\end{array}$ \\
\hline $2700^{\circ} \mathrm{F}$ CMC Components & $\begin{array}{l}\text { Increase allowable turbine vane temperature to } \\
2700^{\circ} \mathrm{F}\end{array}$ \\
\hline Turbomachinery Disk Alloy & Increase allowable $\mathrm{T}_{3}$ temperature to $1350^{\circ} \mathrm{F}$ \\
\hline $\begin{array}{l}\text { Low Conductivity Ceramic TBC for } \\
\text { Turbine Airfoils }\end{array}$ & $\begin{array}{l}\text { Increase allowable turbine blade temperature to } \\
2250^{\circ} \mathrm{F}\end{array}$ \\
\hline Lightweight Nozzle Materials & Reduce mixer-ejector weight (if used) by $10 \%$ \\
\hline $\begin{array}{l}\text { Active Shape Control Technologies for } \\
\text { Variable Radius Inlet Lip }\end{array}$ & Remove inlet blow-in door weight \\
\hline $\begin{array}{l}\text { High Reynolds No. Design Tools for } \\
\text { Advanced Configurations }\end{array}$ & Reduce total $\mathrm{A} / \mathrm{C}$ drag by $1 \%$ \\
\hline Combustor Controls & $\begin{array}{l}\text { Reduce } T_{4} \text { margin requirement (improved pattern } \\
\text { factor) by } 60^{\circ} \mathrm{F}\end{array}$ \\
\hline Adaptive Engine Controls & Reduce engine SFC by $0.5 \%$ \\
\hline
\end{tabular}

Table 3. Technology Suite of the UEETP

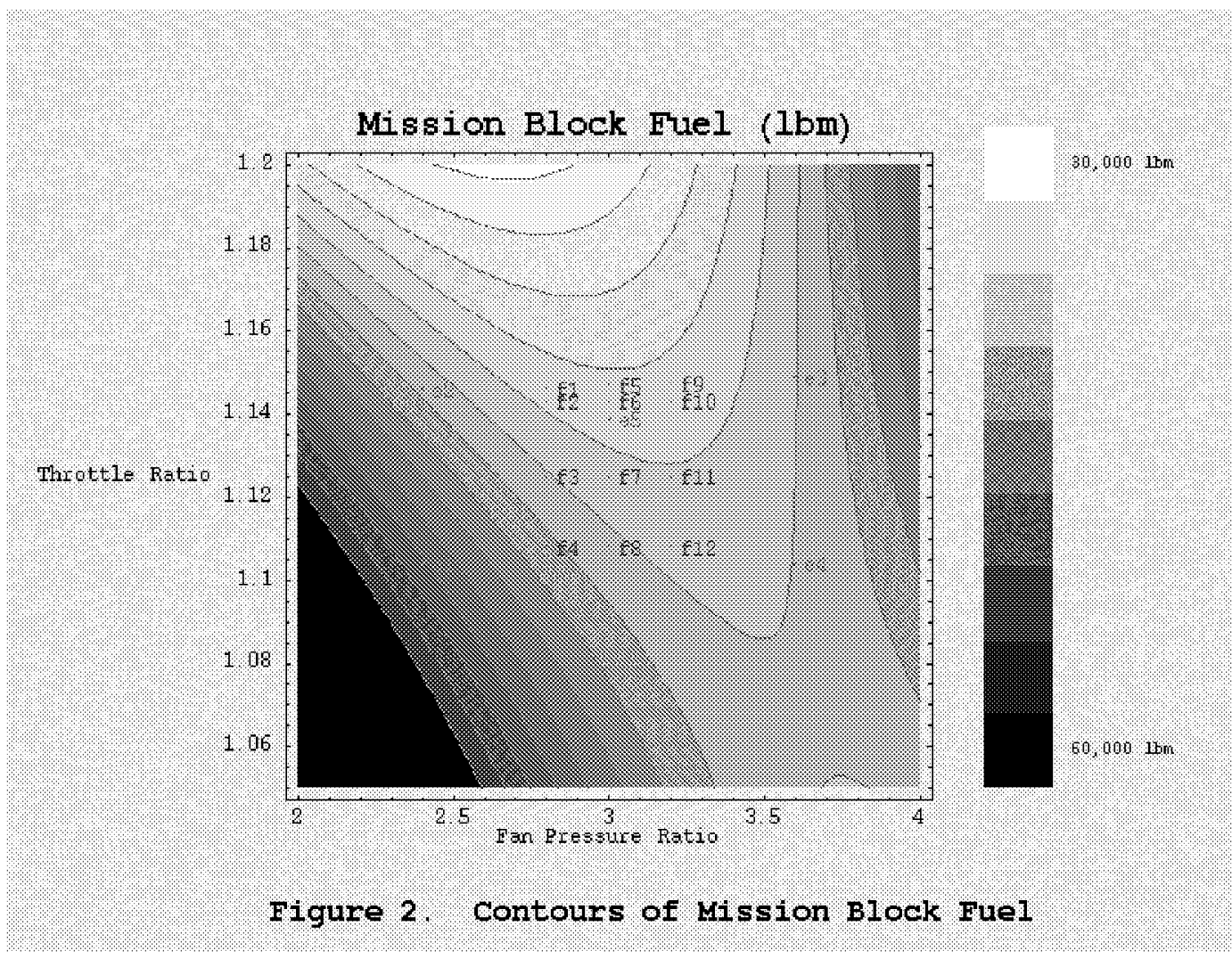




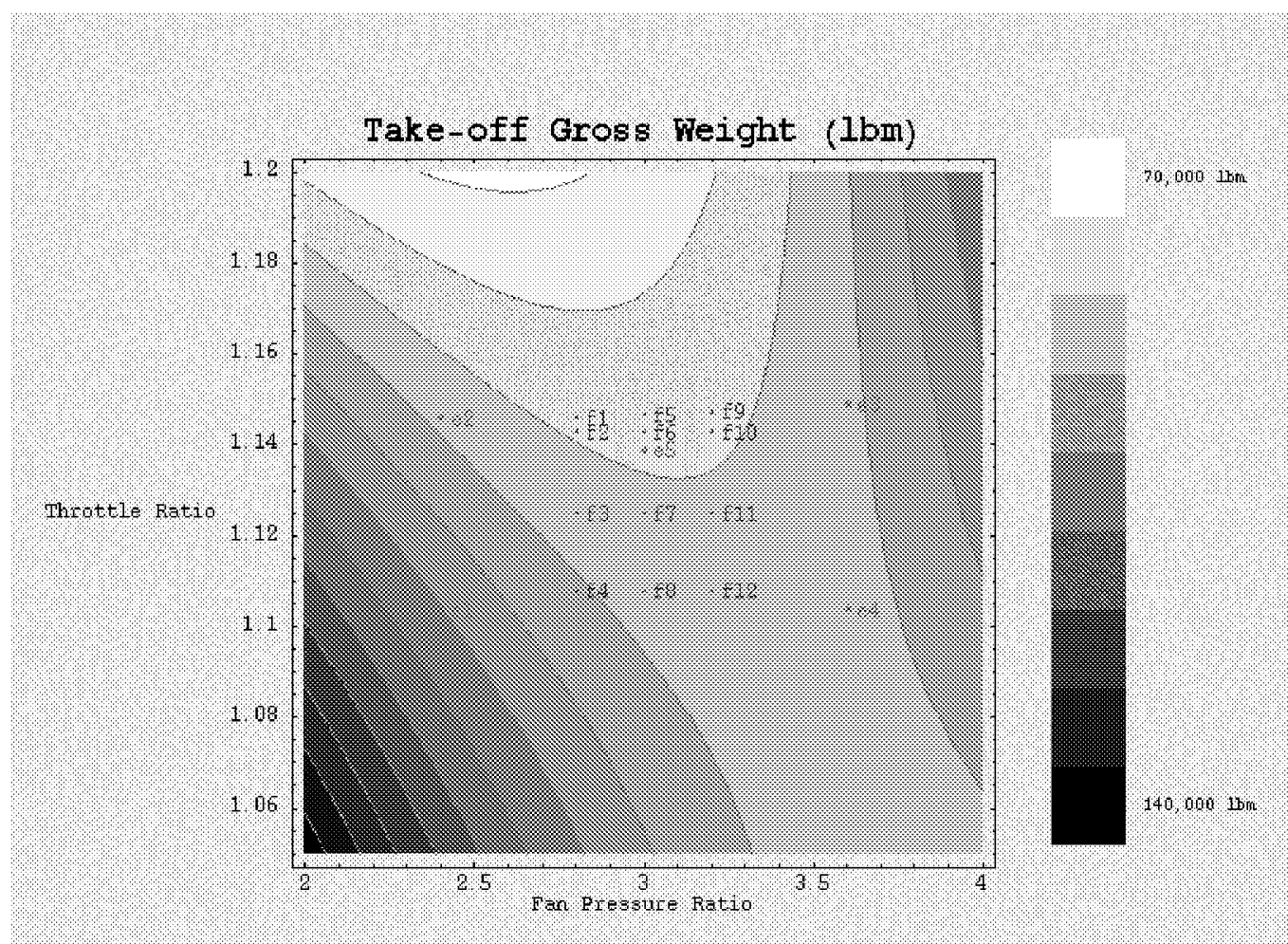

Figure 3 . Contours of Take-off Gross Neight

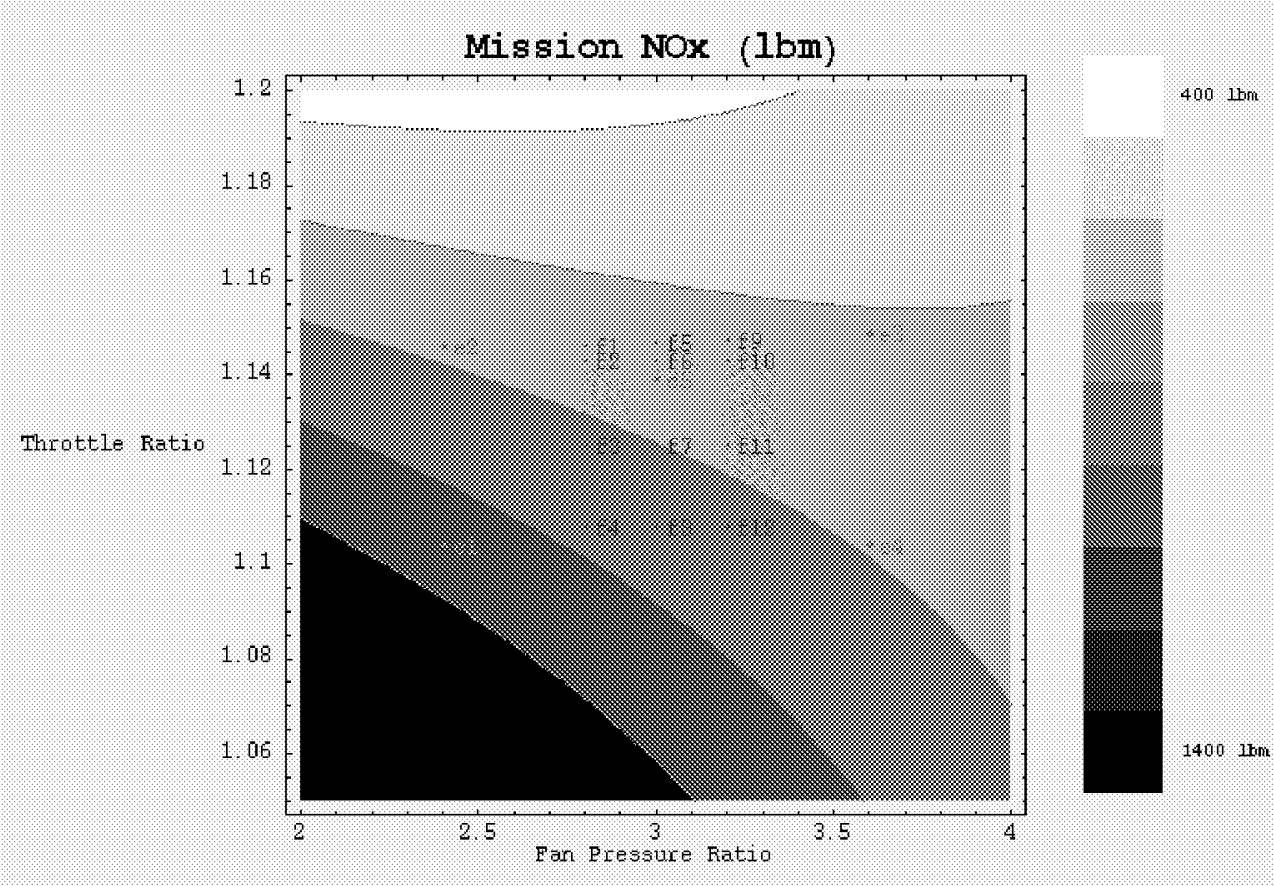

Figure 4. Contours of Mission Nox Emissions 


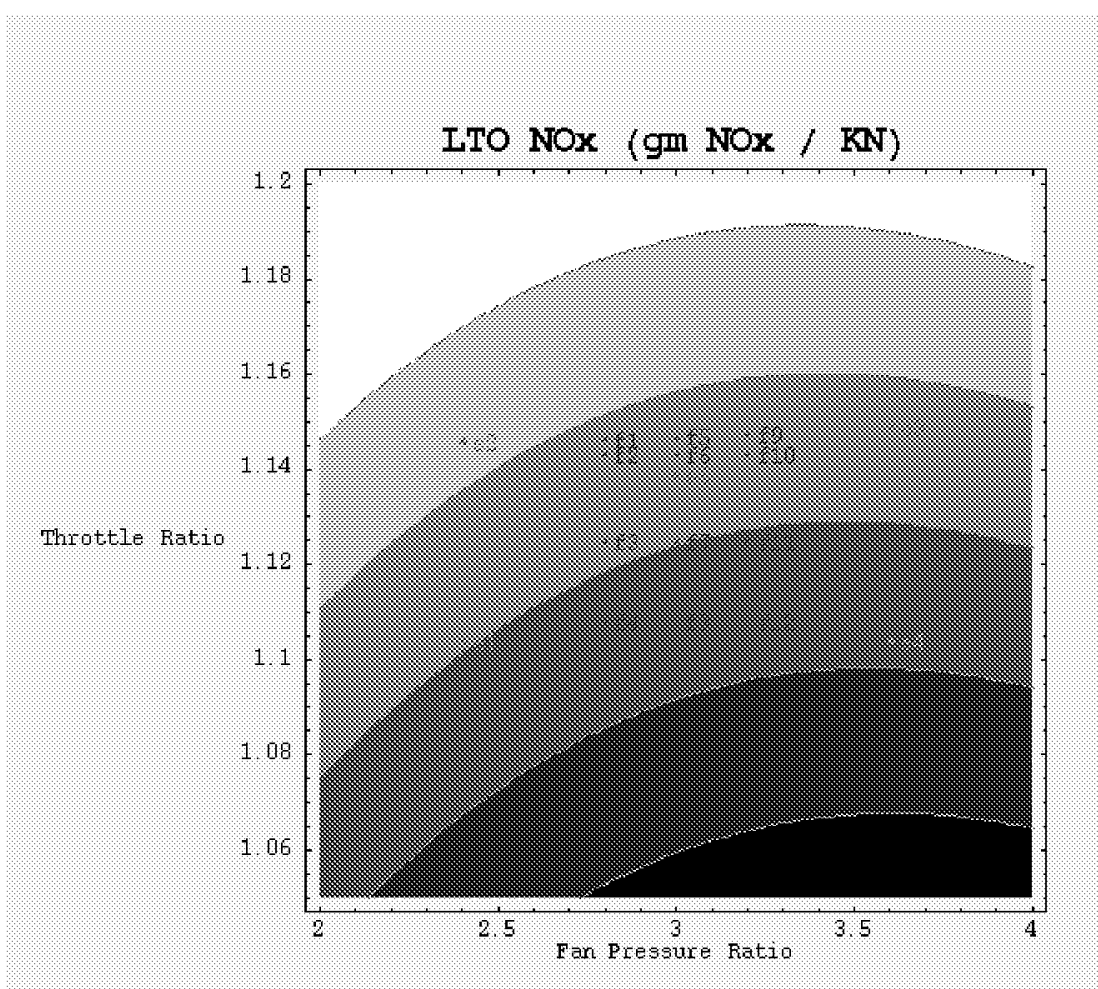

15 gin/row

Figure 5. Contours of ITO-NOX Emissions

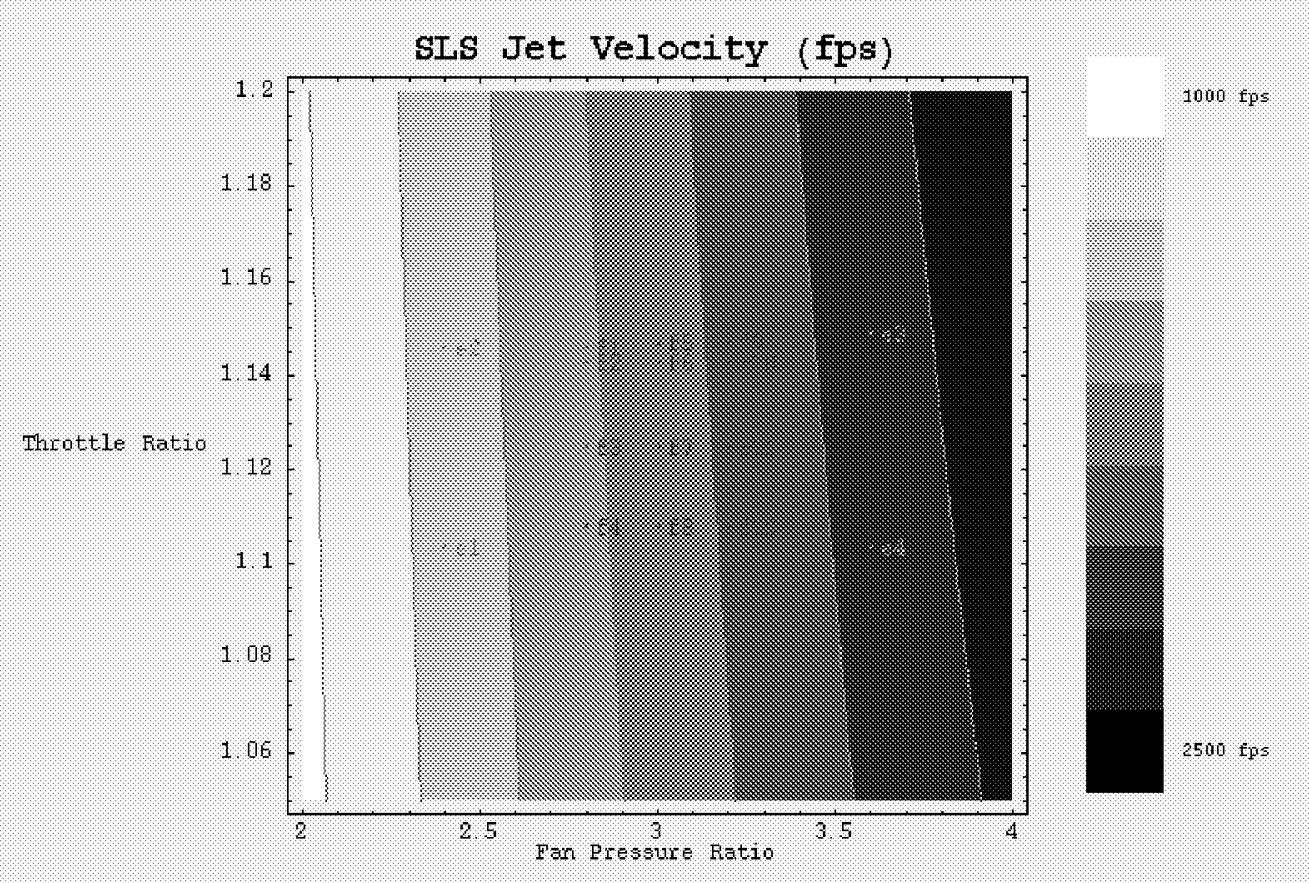

Figure 6. Contours of SLS Jet Velocity 


\begin{tabular}{|c|c|}
\hline \multicolumn{2}{|c|}{ SBJ Baseline Propulsion System } \\
\hline \\
\hline \multicolumn{2}{|c|}{$\begin{array}{l}\text { SBJ Baseline Propulsion System } \\
\text { EPR, } \Phi \\
\text { HPC PR }\end{array}$} \\
\hline \multicolumn{2}{|l|}{ BPR Des } \\
\hline \multirow{3}{*}{$\begin{array}{l}T_{4} \text { Max (deg. R) } \\
T_{4} \text { Des (deg. R) } \\
\text { SLS Jet Velocity (fps) }\end{array}$} & 3600 \\
\hline & 3150 \\
\hline & 1833 \\
\hline \multirow{4}{*}{\begin{tabular}{|l|}
$T T R, \tau$ \\
Wc lapse \\
Fn lapse \\
\end{tabular}} & \\
\hline & \\
\hline & \\
\hline & 0.33 \\
\hline \multirow{4}{*}{$\begin{array}{l}\text { Fn SLS (lbf) } \\
\text { SFC SLS [(lbm/hr)/lbf] } \\
\text { Fn TOC (lbf) } \\
\text { SFC TOC [(lbm/hr)/lbf] }\end{array}$} & 22398 \\
\hline & \% \\
\hline & 7442 \\
\hline & 1102 \\
\hline \multirow{5}{*}{\begin{tabular}{|l|} 
TOGW $(\mathrm{lbm})$ \\
Block Fuel $(\mathrm{lbm})$ \\
LTO $\mathrm{NO}_{\mathrm{x}}(\mathrm{g} \mathrm{NOx} / \mathrm{kN})$ \\
Mission $\mathrm{NO}_{\mathrm{x}}(\mathrm{lbm})$ \\
\end{tabular}} & \\
\hline & 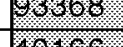 \\
\hline & \\
\hline & 22.33 \\
\hline & \\
\hline
\end{tabular}

Table 4. Current Technology Engine Design Cycle Parameters

\begin{tabular}{|c|c|c|}
\hline $\begin{array}{l}\text { Comparison of the } \mathrm{Ba} \\
\text { Propulsion System }\end{array}$ & seline a & ad UE \\
\hline & Faseline & UEETP \\
\hline & & \\
\hline & & \\
\hline FPR, $\Phi$ & 280 & 3.00 \\
\hline HPC PR & 9.60 & 11.20 \\
\hline BPR Des & 1.21 & 1.88 \\
\hline$\overline{T_{4} \operatorname{Max}(\text { deg. } R)}$ & 3885 & 3600 \\
\hline $\mathrm{T}_{4}$ Des (deg. R) & 3160 & 3150 \\
\hline SLS Jet Velocity (fps) & 1808 & 1833 \\
\hline TTR, $\tau$ & 107 & 1.1 .6 \\
\hline Wc lapse & 6.825 & 0.825 \\
\hline Fn lapse & 6.30 & 1.33 \\
\hline Fn SIS (lbf) & 20.1: & 02308 \\
\hline SFC SLS [(lbm/hr)/lbf] & 1594 & 0.547 \\
\hline Fn TOC (lbf) & 6385 & 7442 \\
\hline SFC TOC $[(\mathrm{lbm} / \mathrm{hr}) / \mathrm{lbf}]$ & 1.170 & 11.102 \\
\hline TOGW $(\mathrm{lbm})$ & 119294 & 93368 \\
\hline Block Fuel (lbm) & 52488 & 40166 \\
\hline LTO NO ${ }_{x}(\mathrm{~g} \mathrm{NOx} / \mathrm{kN})$ & 60.96 & 2233 \\
\hline Mission $\mathrm{NO}_{\mathrm{x}}(\mathrm{lbm})$ & 1427 & 897 \\
\hline$\%$ Below $\mathrm{NO}_{\mathrm{x}}$ Rule & 39.7 & 810 \\
\hline $\begin{array}{l}\% \text { Fuel Burn Reduction } \\
\text { (from baseline) }\end{array}$ & & 23.48 \\
\hline Cost (\$M) & 37.90 & Win \\
\hline Cost Reduction (\%) & & 13.88 \\
\hline LTO-NOx rule (g NOx/KN) & & 1.17 .31 \\
\hline $\begin{array}{l}\text { LTO-NOx reduction from } \\
\text { baseline system (\%) }\end{array}$ & & 63.37 \\
\hline
\end{tabular}

Table 5. Comparison of the Baseline and UEETP SBJ Propulsion System.

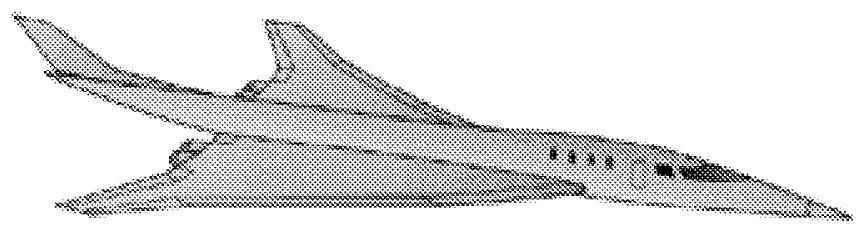




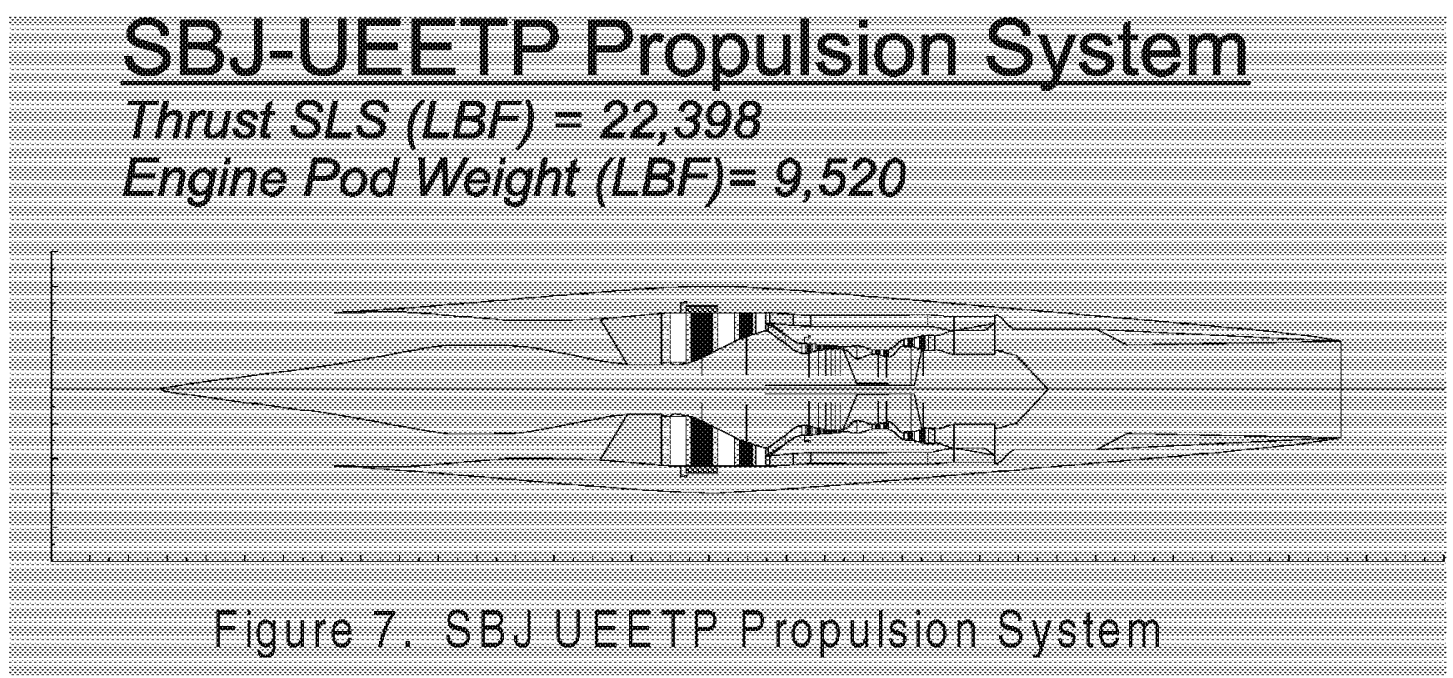


\begin{tabular}{l|l|l|l|}
\hline 1. AGENCY USE ONLY (Leave blank) & 2. REPORT DATE & 3. REPORT TYPE AND DATES COVERED
\end{tabular}

\begin{tabular}{|c|c|c|}
\hline & August 2002 & Technical Memorandum \\
\hline
\end{tabular}

\begin{tabular}{l|l|l} 
4. TITLE AND SUBTITLE & FUNDING NUMBERS
\end{tabular}

Conceptual Design of a Supersonic Business Jet Propulsion System

6. AUTHOR(S)

WU-714-01-10-00

Robert J. Bruckner

7. PERFORMING ORGANIZATION NAME(S) AND ADDRESS(ES)

National Aeronautics and Space Administration

John H. Glenn Research Center at Lewis Field

Cleveland, Ohio 44135-3191

9. SPONSORING/MONITORING AGENCY NAME(S) AND ADORESS(ES)

10. SPONSORING/MONITORING AGENCY REPORT NUMBER

National Aeronautics and Space Administration

Washington, DC 20546-0001

NASA TM-2002-211797

AIAA-2002-3919

\section{SUPPLEMENTARY NOTES}

Prepared for the 38th Joint Propulsion Conference and Exhibit cosponsored by the AIAA, ASME, SAE, and ASEE, Indianapolis, Indiana, July 7-10, 2002. Responsible person, Robert I. Bruckner, organization code 2400, 216-433--6499.

12a. DISTRIBUTION/AVAILABILITY STATEMENT 12b. DISTRIBUTION CODE

Unclassified-Unlimited

Subject Category: 07

Distribution: Nonstandard

Available electronically at mo/glragrcmasia.sow

This publication is available from the NASA Center for AeroSpace Information, 301-621-0390.

13. ABSTRACT (Maximum 200 words)

NASA's Ultra-Efficient Engine Technology Program (UEETP) is developing a suite of technology to enhance the performance of future aircraft propulsion systems. Areas of focus for this suite of technology include: Highly Loaded Turbomachinery, Emissions Reduction, Materials and Structures, Controls, and Propulsion-Airframe Integration. The two major goals of the UEETP are emissions reduction of both landing and take-off nitrogen oxides $\left(\mathrm{LTO}-\mathrm{NO}_{\mathrm{X}}\right)$ and mission carbon dioxide $\left(\mathrm{CO}_{2}\right)$ through fuel burn reductions. The specific goals include a 70 percent reduction in the current $\mathrm{LTO}-\mathrm{NO} \mathrm{X}_{\mathrm{X}}$ rule and an 8 percent reduction in mission $\mathrm{CO}_{2}$ emissions. In order to gain insight into the potential applications and benefits of these technologies on future aircraft, a set of representative flight vehicles was selected for systems level conceptual studies. The Supersonic Business Jet (SBJ) is one of these vehicles. The particular SBJ considered in this study has a capacity of 6 passengers, ctuise Mach Number of 2.0 , and a range of 4,000 nautical miles. Without the current existence of an SBI the study of this vehicle requires a two-phased approach. Initially, a hypothetical baseline SBJ is designed which utilizes only current state of the art technology. Finally, an advanced SBJ propulsion system is designed and optimized which incorporates the advanced technologies under development within the UEETP. System benefits are then evaluated and compared to the program and design requirements. Although the program goals are only concerned with $\mathrm{LTO}-\mathrm{NO}_{\mathrm{X}}$ and $\mathrm{CO}_{2}$ emissions, it is acknowledged that additional concerns for an SBJ include take-off noise, overland supersonic flight, and cruise $\mathrm{NO}_{\mathrm{X}}$ emissions at high altitudes. Propulsion system trade-offs in the conceptual design phase acknowledge these issues as well as the program goals. With the inclusion of UEETP technologies a propulsion system is designed which performs at $81 \%$ below the LTO. No $\mathrm{X}_{\mathrm{X}}$ rule, and reduces fuel burm by 23 percent compared to the current technology.

\section{SUBJECT TERMS}

Jet propulsion; Aircraft engine; Gas turbine engines; Supersonics; Supersonic aircraft

15. NUMBER OF PAGES

16

16. PRICE CODE

\begin{tabular}{|c|c|c|}
\hline $\begin{array}{c}\text { 17. SECURITY CLASSIFICATION } \\
\text { OF REPORT } \\
\text { Unclassified }\end{array}$ & $\begin{array}{c}\text { 18. SECURITY CLASSIFICATION } \\
\text { OF THIS PAGE } \\
\text { Unclassified }\end{array}$ & $\begin{array}{c}\text { 19. SECURTY CLASSIFICATION } \\
\text { OF ABSTRACT } \\
\text { Unclassified }\end{array}$ \\
\hline
\end{tabular}

NSN 7540-01-280-5500 